\title{
Intraspecific variation and polymorphism in the ostracode Conchoprimitia socialis (Brogger, 1882) from the early Middle Ordovician Baltoscandian Palaeobasin
}

\author{
OIVE TINN, TÕNU MEIDA \& KADRI SOHAR
}

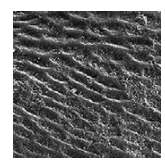

\begin{abstract}
The eridostracan ostracode genus Conchoprimitia Öpik, 1935 appears among the earliest ostracodes in the carbonate succession of the Ordovician Baltoscandian Palaeobasin. Over the past one hundred years, more than twenty species of Conchoprimitia have been recognized from early Middle Ordovician sediments. The microsculpture has been regarded as one of the most important features for distinguishing between different species of Conchoprimitia. However, four main types of microsculpture (smooth, punctate, reticulate and rugose/striate) are often transitional, occurring on different areas of the carapace and are not therefore discrete taxonomically important characters. As no clear distinction can be made between different carapace morphologies, the early Middle Ordovician Conchoprimitia species of Baltoscandia should be regarded as morphotypes of one polymorphic species - Conchoprimitia socialis (Brøgger, 1882). C. socialis was an opportunistic species, which developed different microsculpture on the carapace surface in different lithofacies in the Baltoscandian Palaeobasin. • Key words: ostracodes, Ordovician, Baltoscandia, Conchoprimitia, carapace, polymorphism.
\end{abstract}

TINN, O., MEIDA, T. \& SOHAR, K. 2010. Intraspecific variation and polymorphism in the ostracode Conchoprimitia socialis (Brøgger, 1882) from the early Middle Ordovician Baltoscandian Palaeobasin. Bulletin of Geosciences 85(4), 603-616 (8 figures, 1 table). Czech Geological Survey, Prague. ISSN 1214-1119. Manuscript received February 1, 2010; accepted in revised form September 7, 2010; published online November 3, 2010; issued December 20, 2010.

Oive Tinn (corresponding author), Tõnu Meidla \& Kadri Sohar, Department of Geology, Institute of Ecology and Earth Sciences, University of Tartu, Ravila 14a, 50411,Estonia; oive.tinn@ut.ee

For measuring biodiversity both in recent and ancient ecosystems, the importance of systematics and the quality of taxonomic work cannot be overestimated. The development of molecular methods has led to a realisation that our diversity estimates in recent ecosystems may be underestimated because of numerous taxa which are difficult to classify by means of traditional (morphological) taxonomic methods. Recognising cryptic biodiversity in fossil ecosystems is more complicated as the character of fossil material only permits the use of morphological data. Recent studies (Siveter 2008) have also demonstrated that without knowledge of soft-part anatomy, the taxonomy of fossil ostracodes is even more complicated. In addition, several geological disciplines, such as palaeoecology and biostratigraphy, rely on the correctness of fossil classification, and this makes studies on taxonomy of various fossils justified and timely.

Ostracodes, microscopic crustaceans (usually 1-2 mm), with a distinctive bivalved carapace, are widely used in palaeoecology and biostratigraphy because of their relatively short stratigraphic ranges and high abundance in shelf sequences (Tinn \& Meidla 2001, Williams et al. 2005, Tinn et al. 2006). The systematics of recent ostracodes is based on soft body anatomy and the carapace features are of secondary importance. Fossil ostracode taxonomy relies, albeit with rare examples of soft anatomy (Siveter et al. 2003, Siveter 2008) almost entirely on the morphologies of the calcitic bivalved carapace.

Ostracodes are also prone to two controversial phenomena: polymorphism, where one species can show a variety of different morphologies (Ducasse et al. 1990, Carbonel \& Hamoudi 1990, Neil 2000), and convergence, where different species show similar morphology (Park et al. 2002, Park \& Ricketts 2003, Tinn \& Oakley 2008). If these problems are not sufficiently considered many new, but essentially, erroneous taxa will result, especially in cases with very simple carapace morphologies.

A simple, almost "featureless" ostracode taxon is the eridostracan genus Conchoprimitia Öpik, 1935, which appeared with the earliest ostracodes in the Ordovician Baltoscandian Palaeobasin (Meidla et al. 1998, Melnikova 1999, Tinn 2002). The genus persisted until the Late Ordovician and was distributed over most of the Baltoscandian Palaeobasin. Species of Conchoprimitia have been recorded from Norway (Brøgger 1882, Öpik 1939, 


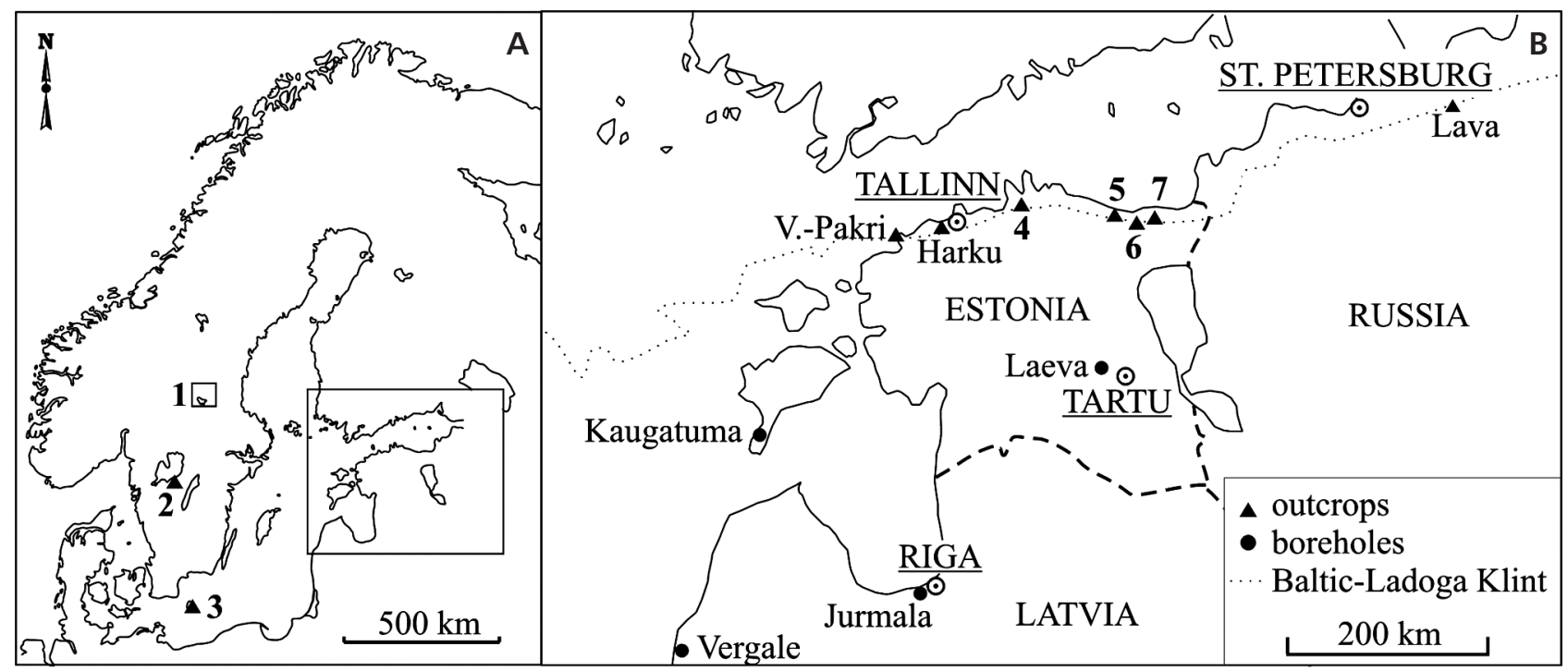

Figure 1. Map showing outcrops and boreholes. Localities indicated by numbers: 1 - localities in the Siljan area; 2 - Hällekis; 3 - Skelbro; 4 - Nõmmeveski; 5 - Saka; 6 - Toila; 7 - Päite.

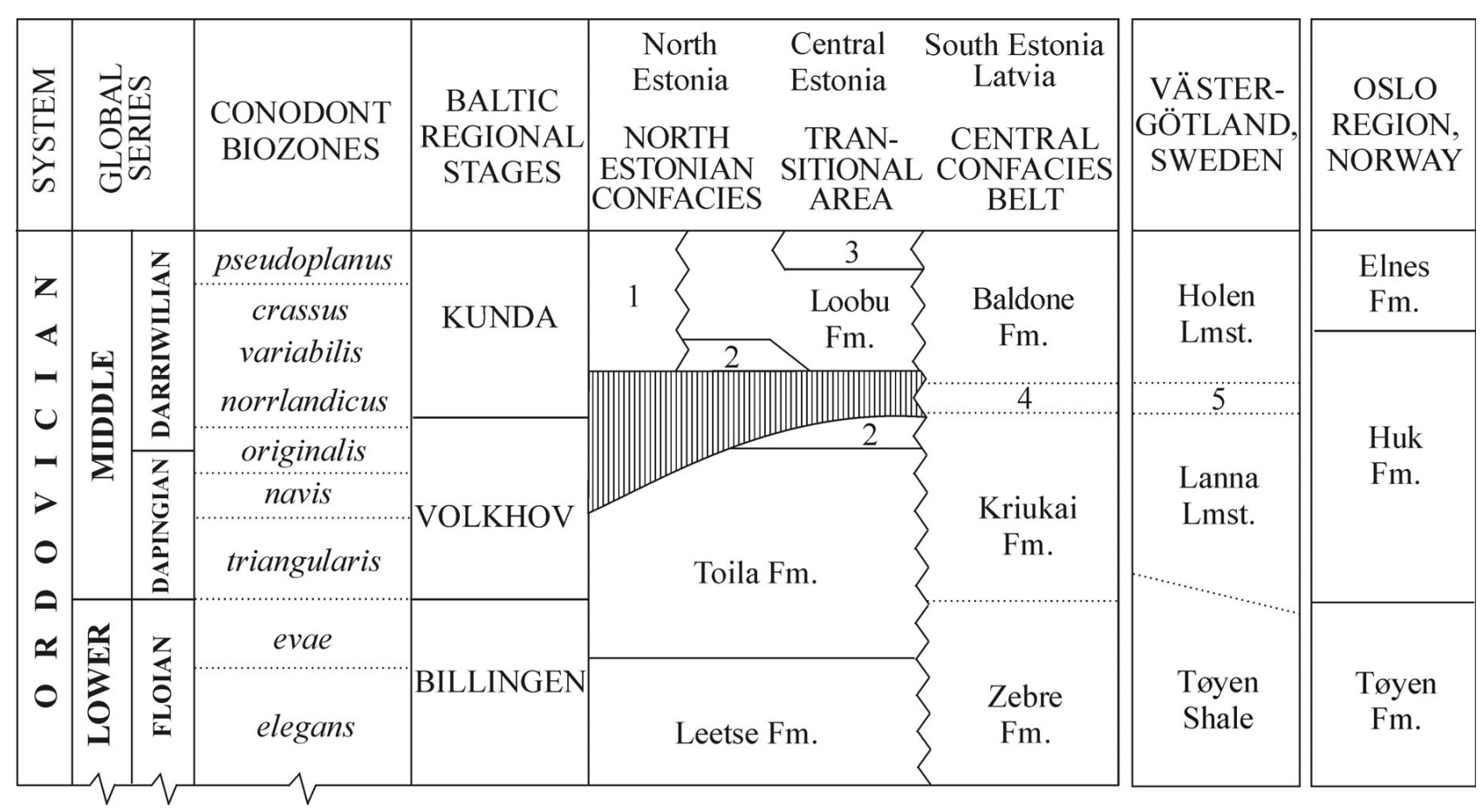

Figure 2. Stratigraphic framework for the Lower and Middle Ordovician strata of the studied area, correlated with conodont biozones (Löfgren 1995, 2000; Nõlvak et al. 2006). Data for Västergötland from Jaanusson (1982) and Dronov et al. (2001); Oslo region from Owen et al. (1990). Numbers indicate: 1 - Pakri Formation; 2 - Sillaoru Formation; 3 - Rokishkis Formation; 4 - Shakyna Formation; 5 - Täljsten.

Henningsmoen 1954), Sweden (Thorslund 1940, Hessland 1949, Jaanusson 1957, Tinn \& Meidla 2001), Estonia (Öpik 1935, Sarv 1959), Latvia (Ainsaar et al. 2002), Lithuania (Sidaravičienè 1992), as well as from numerous erratic boulders in Germany (Krause 1889, 1891; Steusloff 1895; Kummerow 1924; Schallreuter 1993 and references therein). All this material originates from the same area, representing a relatively shallow epicontinental Baltoscandian Palaeobasin.

Altogether, more than 20 species have been referred to Conchoprimitia. The stratigraphic distribution of Conchoprimitia species from the Floian to lower Darriwilian (Billingen, Volkhov and Kunda regional stages) of Baltoscandia is presented in Table 1. Conchoprimitia is 


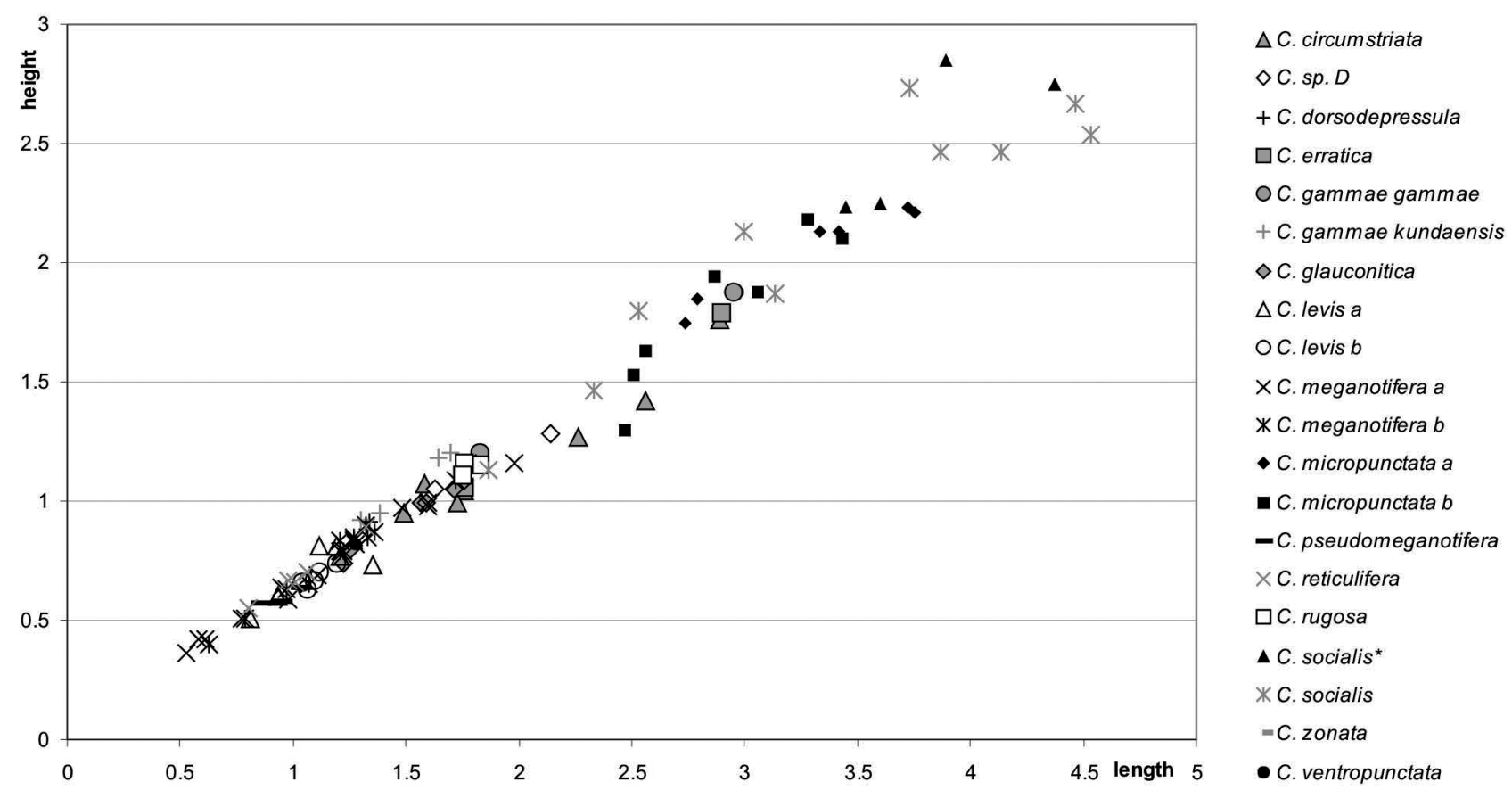

Figure 3. Size distribution of previously described Conchoprimitia-species.

characterized by simple morphology: a long hinge line, left over right valve overlap, postplete outline, and more or less convex carapace without distinct lobes and sulci. The valves occasionally show moult retention which is typical for eridostracans. The specimens attained a relatively large size, exceeding $4 \mathrm{~mm}$ [max $4.5 \mathrm{~mm}$ : Henningsmoen (1954) - C. socialis socialis (Brøgger, 1882)] in length. Such "featureless" morphology is probably the reason why large numbers of specimens have been collected and studied for over more than a century, and have been attributed to numerous different species and subspecies. Comparison of collections from different parts of the Baltoscandian Palaeobasin allows us to suggest that in several previously established species, the type material consists of juveniles/preadults and this makes a comparative study more complicated.

Recent comprehensive research on lower Middle Ordovician ostracode faunas (Tinn 2002, Tinn et al. 2006) revealed difficulties in the practical differentiation between species. This paper focusses on: 1) a critical analysis of the morphological features of Conchoprimitia; 2) an analysis of the species concept and variability in Conchoprimitia; 3) a revision of Conchoprimitia species in the early Middle Ordovician Baltoscandian Palaeobasin.

\section{Material and methods}

We analysed the stratigraphic interval in which the species diversity of Conchoprimitia was at its greatest - the top- most Lower Ordovician to lower Middle Ordovician (Floian to Darriwilian stages) (Fig. 2). We re-examined the type material of Brøgger (1882), Öpik (1935, 1939), Hessland (1949), Sarv (1959) and Henningsmoen (1954) supplemented by numerous new specimens collected by the authors in different parts of the Baltoscandian area (Fig. 1). The new samples are particularly important for analysis of variation as older type collections usually contain just one or a small number of specimens.

The genus Conchoprimitia was erected by A. Öpik in 1935. Öpik's (1935) type material is from Tallinn (Fig. 1), from the upper part of the Volkhov Stage. J. Bock's ostracod collection from Obukhovo, St. Petersburg region, Russia, was used as paratypes by Öpik (1935). At the moment both, Öpik's and Bock's collections are integrated into the ostracod collection belonging to the Institute of Geology at the Tallinn University of Technology.

The holotype for Conchoprmitia socialis (Brøgger, 1882), described by Öpik (1939) comes from Slemmestad, Røyken, Norway, from the Huk Formation ( $3 \mathrm{c} \gamma$ ) [old term, see Owen et al. 1990].

Hessland's (1949) type material is from the Siljan district, Sweden (Fig. 1). It was collected from the Täljsten layer (Fig. 2), (uppermost Dapingian and lower Darriwilian), throughout its entire thickness; the underlying Lanna Limestone was sampled from its uppermost part and the overlying Holen Limestone from its lower part only. The type material of $C$. socialis is represented by limestone slabs with a diameter of 5-50 $\mathrm{mm}$ in which the ostracodes were prepared using fine needles. The preservation quality 


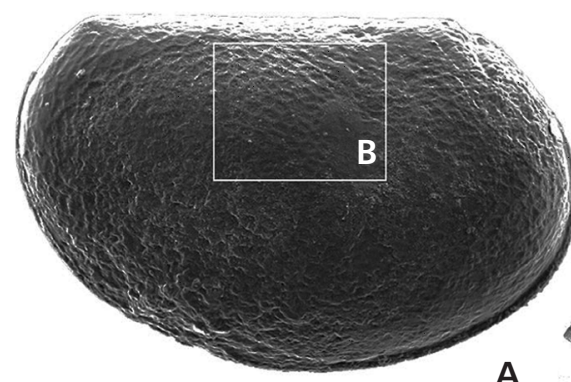

A

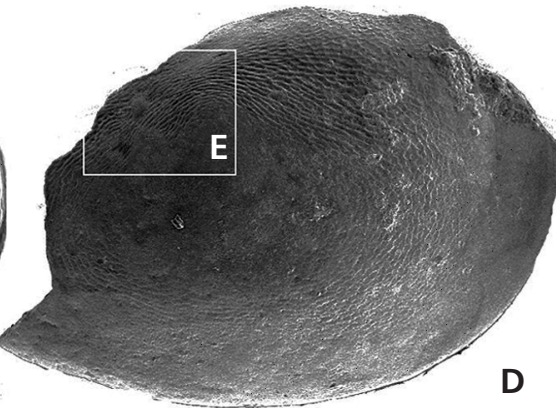

D
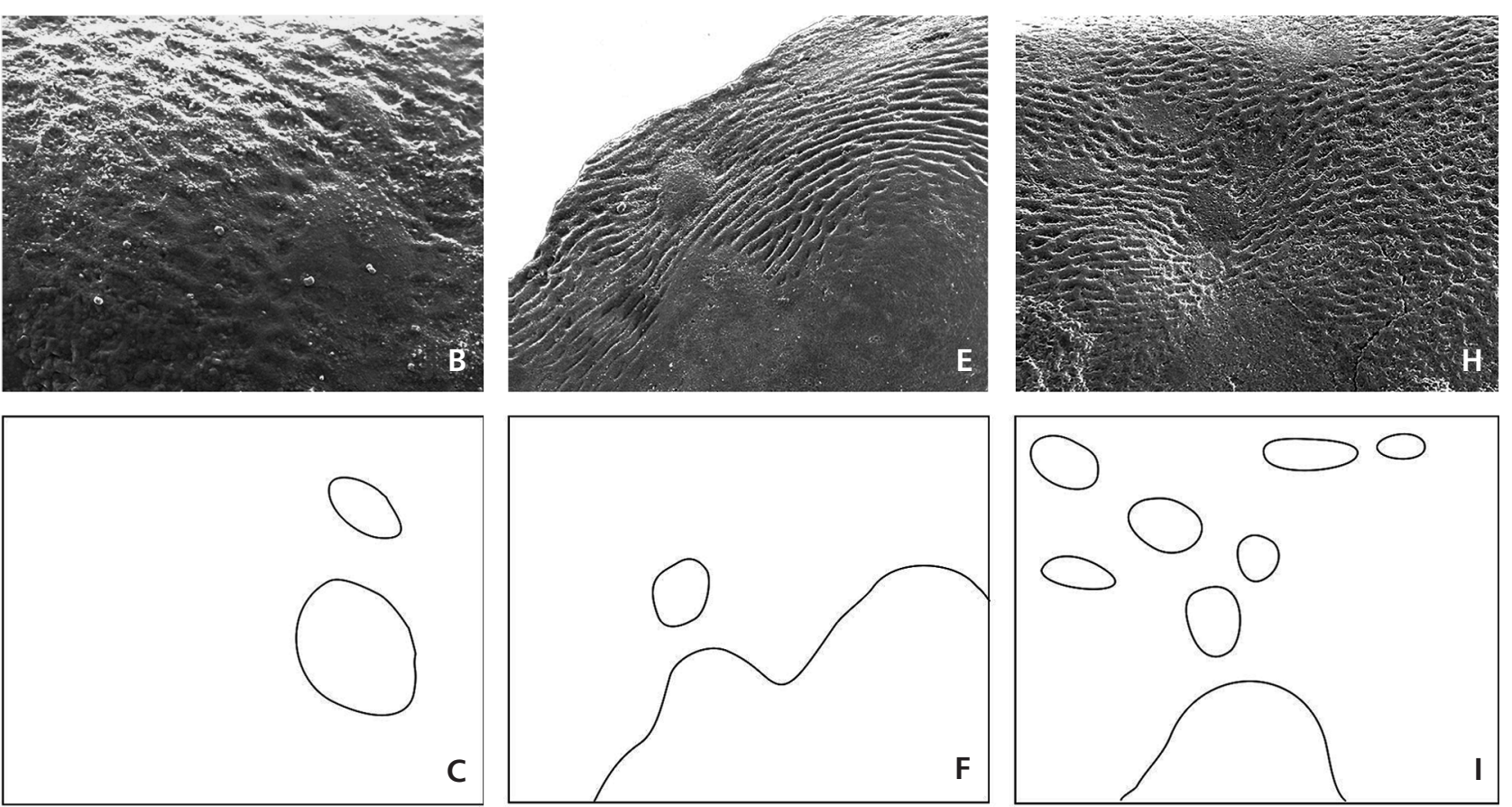

Figure 4. Muscle scars on the external surface of Conchoprimitia socialis. • A - TUG 1199/1, right valve, $\times 62$, Jurmala section, sample 21 , Kunda Stage; B, C × 190. • D - TUG 1199/2, left valve, × 23, Hällekis section, sample 20, Kunda Stage; E, F × 75. • G - TUG 1199/3, left valve, × 19, Hällekis section, sample 224 , Kunda stage; $\mathrm{H}, \mathrm{I} \times 75$.

of the material is variable. The best preserved specimens show undamaged calcitic valves with fine sculpture. However, a number of specimens are broken and some of the material has been preserved as internal moulds only.

New material for the present study comes from numerous sections of the Baltoscandian area (Fig. 1). The western sections are represented by Hällekis in Västergötland (including also the Täljsten interval studied by Hessland) and Skelbro in Bornholm (Denmark). A large amount of material comes from the eastern Baltic-Ladoga Klint: Väike-Pakri, Harku, Nõmmeveski, Saka, Toila and Päite in Estonia and Lava section in St. Petersburg Region, Russia. Additionally, material from several boreholes was included - Kaugatuma and Laeva-8 in southern Estonia, Jurmala R-1 and Vergale-50 in Latvia.

Most of the samples were processed using a standard physical disintegration method, which is comparable to natural weathering. The crushed limestone samples, 0.5 to
$1.5 \mathrm{~kg}$, were disintegrated with sodium thiosulphate pentahydrate (also known as sodium hyposulphite) as a crystallizing agent. To obtain a satisfactory degree of disaggregation, heating and cooling cycles were repeated up to 10 times for clay-rich marls and some 30 times for hard limestones. Ostracode material from clay layers was obtained by washing through $0.25-2 \mathrm{~mm}$ sieves. The ostracode material studied is of variable quality, but mostly well preserved. Secondary dolomitisation affected ostracode carapaces from the Billingen Stage (Floian) in Lava, Russia.

The total number of studied specimens exceeded 2000. Selected specimens were photographed using the scanning electron microscope (SEM) JEOL at the Centre of Material Research, Tallinn Technical University.

The studied material is deposited in the Museum of Natural History, University of Tartu (TUG); The Institute of Geology, Tallinn Technical University (IGT) and The Palaeontological Museum of Oslo (PMO). 


\section{Carapace size}

Conchoprimitia is characterized by large valves ( 1 to $3 \mathrm{~mm}$ ), but occasionally exceeding $4 \mathrm{~mm}$ in length. Data on the size and proportions of the carapaces and valves are shown in Fig. 3. The scatter plot shows the size distribution of 19 Conchoprimitia "species", "subspecies" and "varieties", from the Middle Ordovician of Baltoscandia as recorded by different authors. The plot displays a linear distribution of data points, with the greatest number of specimens in the lower half of the size range. The younger juvenile stages are recorded less often. The largest recorded specimens, up to $4.5 \mathrm{~mm}$, were designated as $C$. socialis by Brøgger (1882), Henningsmoen (1954) and Hessland (1949). The size of other type and original specimens is substantially smaller; judging from the descriptions the largest size of the established taxa varies between 1 and $2.5 \mathrm{~mm}$. The most frequent size (12 in total) is represented by the 1 to $1.5 \mathrm{~mm}$ length category, frequency decreased as size increased ( 8 from the 1.5 to $2 \mathrm{~mm}$ length interval, 4 from the 2 to $2.5 \mathrm{~mm}$ interval), whereas all species, subspecies and varieties analyzed during this research are of similar size without any remarkable deviation. The length /height ratios of the type specimens show a nearly linear distribution (Fig. 3). The prevalence of medium- and small-sized species is relatively obvious. This result could be expected as large carapaces are less frequently found in crushed/weathered limestone samples. The size distribution does not reveal any distinctive size groups.

\section{Morphology}

In 1937, Öpik wrote (p. 10), that "Conchoprimitia is a widely variable genus: sulcus and node, the concentric grooves, and the punctation are in some cases well developed, in other cases these appear undefined or lacking".

The morphological elements that have been used for distinguishing Conchoprimitia species are: outline of the carapace, convexity of the carapace, character of the dorsal angles, structure of the muscle field area (nodes, sulci), valve retention-caused features (concentric grooves), valve (micro)sculpture.

However, the distinction between species according to such characters has often been arbitrary, as the parameters were rarely measured accurately, variation was not considered and ontogeny not studied in detail.

Figure 5. Muscle scars and nodes on the external surface of Conchoprimitia socialis. • A - TUG 1199/4, right valve, $\times 75$, Jurmala section, sample 20, Kunda Stage; B $\times 160$. $\bullet$ C - TUG 1199/5, right valve, $\times 37$, Lava section, sample 4, Billingen Stage; $\mathrm{D} \times 125$.
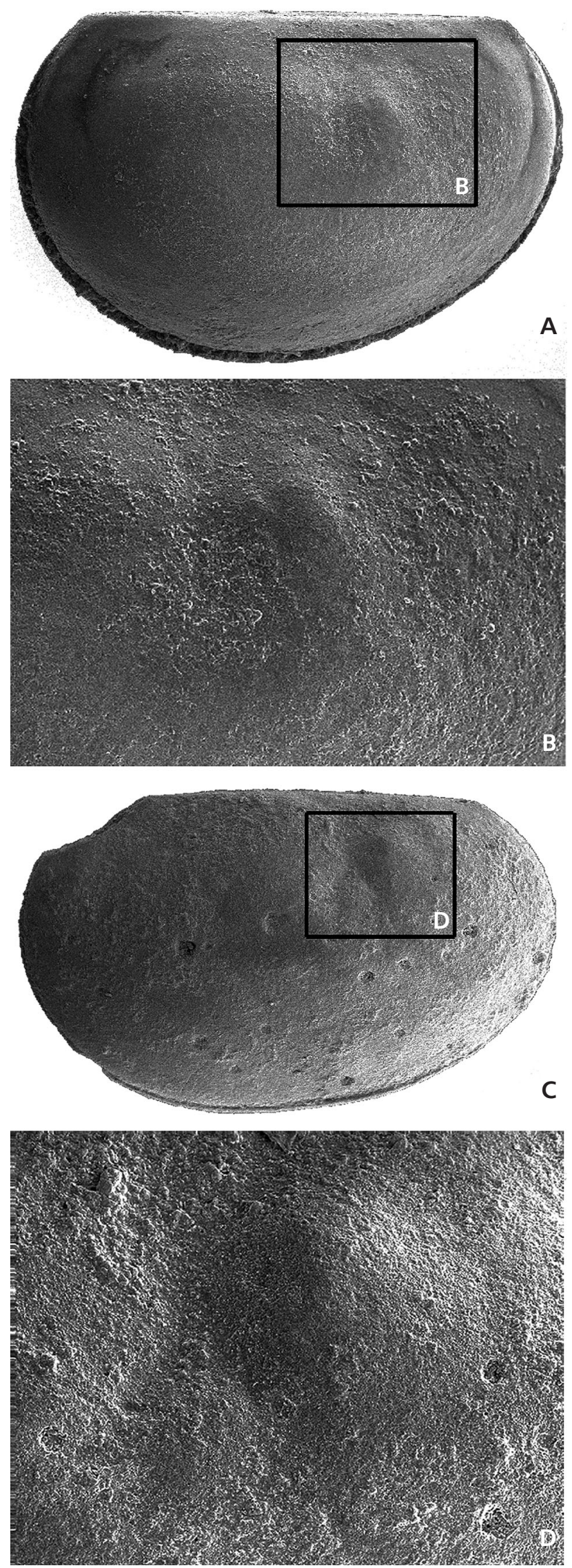
Table 1. Species of the genus Conchoprimitia, recorded from the Lower and Middle Ordovician of the Baltoscandian area. Asterisk (*) marks record in bedrock, e - erratics. All mentioned species are regarded as one polymorphic species, Conchoprimitia socialis (Brøgger).

\begin{tabular}{|c|c|c|c|c|}
\hline & \multicolumn{3}{|c|}{ Regional stage } & \multirow{2}{*}{ Microsculpture/sulcation } \\
\hline & Billingen & Volkhov & Kunda & \\
\hline Conchoprimitia suavia (Melnikova, 1999) & $*$ & & & without carapace microsculpture \\
\hline C. leonidi Melnikova, 1999 & $*$ & & & without carapace microsculpture \\
\hline C. gammae gammae Öpik, 1935 & & $* \mathrm{e}$ & & smooth, well developed concentric grooves \\
\hline C. glauconitica (Kummerow, 1924) & & * & & undefined node, minutely punctate, with imperfect concentric grooves \\
\hline C. zonata (Öpik, 1935) & & $*$ & & without carapace microsculpture, clear short and narrow sulcus \\
\hline C. pseudomeganotifera Schallreuter, 1993 & & $* \mathrm{e}$ & & smooth central part surrounded by pitted/reticulate area \\
\hline C. erratica (Krause, 1889) & & $* \mathrm{e}$ & & fine reticulation \\
\hline C. eos Henningsmoes, 1954 & & * & & appearing smooth, but slightly rough, without distinct pits or granules \\
\hline C. socialis vulgaris Henningsmoen, 1954 & & $*$ & & minutely punctate, with some larger pits \\
\hline C. gammae kundaensis Sarv, 1959 & & & $*$ & smooth surface, without nodes and sulci \\
\hline C. distincta Sarv, 1959 & & & $*$ & smooth central part surrounded by pitted area \\
\hline C. excelsa (Steusloff, 1895) & & & $\mathrm{e}$ & smooth surface \\
\hline C. socialis (Brögger, 1882) & & & $*$ & non-punctate/shallowly pitted surface \\
\hline Conchoides levis Hessland, 1949 & & & $*$ & mostly smooth (type $\alpha$ ) / microstriate (type $\beta$ ) \\
\hline Conchoides micropunctata Hessland, 1949 & & & $*$ & minutely punctate \\
\hline Conchoides meganotifera Hessland, 1949 & & & $*$ & minutely pitted or reticulate surface (type $\alpha$ ) / finely rugose (type $\beta$ ) \\
\hline Conchoides rugosa Hessland, 1949 & & & $*$ & central rugose area, anterior and posterior area striate \\
\hline Conchoides dorsodepressula Hessland, 1949 & & & $*$ & extremely fine reticulation in the dorsocentral area \\
\hline Conchoides circumstriata Hessland, 1949 & & & $*$ & smooth central region, surrounded by striate (reticulete) zone \\
\hline Conchoides ventropunctata Hessland, 1949 & & & $*$ & slightly rugose surface, centroventral field distinctly punctate \\
\hline Conchioides reticulifera Hessland, 1949 & & & $*$ & reticulate surface, marginal zones smooth or faintly rugose \\
\hline
\end{tabular}

\section{Nodes, sulci and muscle field}

The muscle field of Conchoprimitia is discernible as the scar of the adductorial muscle, the preadductorial node, and in some cases also as the scars probably belonging to the mandibular, antennular, and the dorsal group of muscles (Fig. 4; Hessland 1949, pp. 120, 121; Jaanusson 1957, pp. 419, 421, 422). Originally, the type species of the genus, C. gammae, was described as lacking nodes and sulci (Öpik 1935, 1937). Sarv (1959, pp. 164, 165), however, noted that in the anterodorsal part of the carapace in some specimens of $C$. gammae gammae, a shallow vertical sulcus with a length of $1 / 3$ to $1 / 4$ of the carapace height and an indefinite node in front of it was visible. He also mentioned that in occasional specimens the node and sulcus were underdeveloped, and in most juveniles they were almost indiscernible. Also, according to Sarv's (1959) diagnosis, the absence of the sulcal depression served as one of the main characters for distinguishing between C. gammae gammae and $C$. gammae kundaensis. The third species from the Volkhov Stage (Dapingian) of Estonia - C. zonata (Öpik, 1935) - was described as a species with a clearly distinguishable short, narrow sulcus. Considering the observations by Sarv (1959), distinguishing several species of Volkhov age (Dapingian) in samples from Estonia, they appear relatively arbitrary and it is impossible to do so with a larger collection.

The Kunda Stage (lower Darriwilian) material studied in the new collection shows considerable variation in the morphology of the adductorial area. Fig. 4 shows specimens with shallow sulcal depressions and unornamented adductorial spots, but without preadductorial nodes. Fig. 5 shows a specimen with a distinct, but shallow sulcal depression and a preadductorial node in front of it. Commonly specimens lack any mark on the muscle field (Fig. 6). Considerable variation in morphology of the ad-

Figure 6. Different types of punctate sculpture on the carapace of Conchoprimitia socialis. $\bullet$ A - TUG 1199/11, left valve, $\times 25$. Lava section, sample 46, Volkhov Stage; B × 105, C × 340. • D - TUG 1199/12, left valve, × 30. Toila section, sample 2, Volkhov Stage; E × 105, F × 340. • G - TUG 1199/13, right valve, $\times 35$. Toila section, sample 2, Volkhov Stage; H $\times 105, \mathrm{I} \times 105 . \bullet$ J - TUG 1199/14, right valve, $\times 30$. Lava section, sample 45, Volkhov Stage; $\mathrm{K} \times 105, \mathrm{~L} \times 340 . \cdot \mathrm{M}-\mathrm{TUG} 1199 / 15$, left valve, $\times 25$. Nõmmeveski section, sample 21b, Volkhov Stage; $\mathrm{N} \times 70, \mathrm{O} \times 180$. 
Oive Tinn et al. - Intraspecific variation and polymorphism in the ostracode Conchoprimitia
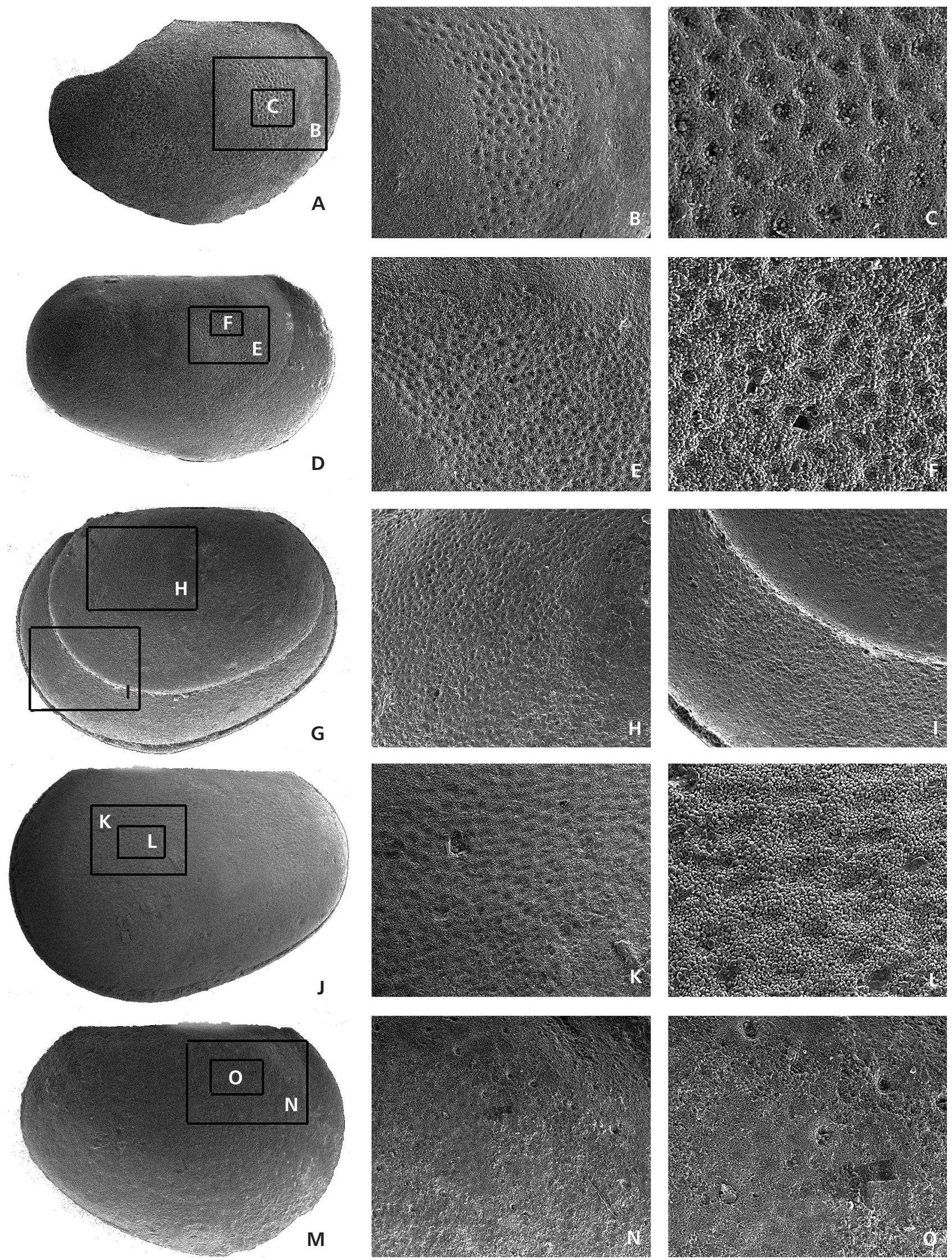
ductorial-anterodorsal area can be recognised in specimens from one locality or even one sample (e.g. Nõmmeveski section and Siljan area), although a full spectrum of different varieties is usually not represented in such cases. No correlation between the size/age of the specimen and the presence or absence of the adductorial scar was revealed.

\section{Valve retention features}

Concentric grooves were not recognised as retention features in the initial descriptions. The first two "species" to be described, C. gammae and C. glauconitica, by Kummerow show two and one concentric grooves, respectively. The presence of a concentric groove in $C$. zonata (Öpik) (initially regarded as Primitia), was mentioned by Öpik (1935). In 1937, Öpik described a new subspecies $C$. tolli integra on the basis of "the total absence of the concentric grooves" (p. 11), while the presence of the groove on the valves of the main subspecies was considered an important feature. Moult retention, although a rare feature in ostracodes, is a common feature among all eridostracans (Adamczak 1961, Vannier et al. 1989, Schallreuter 1977). Nevertheless, specimens of Conchoprimitia with retained valves are rare in the new collection, constituting no more than a few percent of all specimens. The largest number of retained valves revealed on one specimen is two, meaning that the specimen shows three coherent valves (see Tinn \& Meidla 2003, text-fig. 5C). A considerable number of specimens show retention marks, either as complete concentric impressions, reaching from the anterior to the posterior region, or as partial impressions visible in some parts of the carapace only. However, the majority of the specimens in the samples where retention-related features were recorded do not show retention marks. The occasional occurrence of retention-related features should therefore not serve as a character for distinguishing species.

Emphasizing the importance of grooves and shallow sulci on the carapace surface, Hessland (1949) defined Conchoprimitia with two concentric grooves as being nonsulcate, whilst he reassigned some Conchoprimitia species to Conchoides (with one concentric groove, nonsulcate) and Conchoprimites (with sulcus and with or without concentric grooves). However, it is obvious that occasional retention of one (or rarely two) valve(s) cannot be considered a diagnostic feature even at the subspecies level and this fact also discards the taxonomic value of the "species" distinguished according to this feature.

\section{Micro-sculpture}

Öpik (1937) discussed the variability of morphology of Conchoprimitia and noted (p. 10), that in some cases, punctation is well developed, while in the other cases it appears to be undefined or lacking. Micro-sculpture has historically been regarded as one of the most important features for distinguishing species of Conchoprimitia. Generally, the valve surface has been described as smooth, punctate/pitted, rugose/striate, or reticulate. Distinctions have also been made according to the extent or position of the ornamented area, the size and density of punctae on the valve surface and the character of the striae/rugae.

C. gammae (Öpik) and C. zonata (Öpik), from the Volkhov Stage (Dapingian) in North Estonia, and $C$. suavia (Melnikova) and C. leonidi (Melnikova) from the St. Petersburg region have been described as lacking any carapace micro-sculpture. Although C. socialis was also described as non-punctate by Brøgger (1882) and Öpik (1939), the shallowly pitted surface of $C$. socialis was mentioned by Hessland (1949), and described by Henningsmoen (1954) as very finely pitted, except for the region of the adductorial muscle scar and the "shield-like swelling". The occurrence of some scattered larger pits was also mentioned by Henningsmoen. According to the description of Henningsmoen (1954), the external surface of $C$. socialis vulgaris was densely covered with fine pits, with some larger pits scattered inbetween. As in $C$. socialis socialis, the pits were not developed in the muscle scar region and on the shield-like swelling.

Conchoprimitia eos Henningsmoen, 1954 (p. 48) from Norway was described as "appearing smooth, but slightly rough, although there are no distinct pits or granules". Conchoprimitia glauconitica Kummerow was described as possessing a minutely punctate surface. Hessland (1949) described species of the newly erected genera Conchoides and Conchoprimites from the Siljan District, Sweden as having variably smooth, punctate, striate, or partly reticulate surfaces, with a smooth central shieldlike swelling.

Conchoides micropunctata Hessland, 1949 was divided into types $\alpha$ and $\beta$ according to minor differences in punctation. Both types were described by Hessland

Figure 7. Different types of reticulate and rugose sculpture on the carapace of Conchoprimitia socialis. • A - TUG $1199 / 6$, right valve, $\times 36$. Hällekis section, sample 20, Kunda Stage; B $\times 80$. • C - TUG 1199/7, left valve, $\times 70$. Jurmala section, sample 21, Kunda stage; D $\times 210$. $・$ E - TUG $1199 / 3$, left valve, $\times 23$. Hällekis section, sample 20, Kunda Stage; F $\times 75 . \bullet$ G - TUG 1199/8, left valve, $\times 20$. Laeva core section, sample 17 , Kunda Stage; H $\times 75$, I $\times 75$. $•$ J - TUG 1199/9, left valve, $\times 30$. Harku section, sample 243 . Volkhov Stage; K × 110, L × 110. • M - TUG 1199/10, left valve, $\times 30$. Nõmmeveski section, sample 33, Kunda Stage; $\mathrm{N} \times 110, \mathrm{O} \times 180$. 
Oive Tinn et al. - Intraspecific variation and polymorphism in the ostracode Conchoprimitia
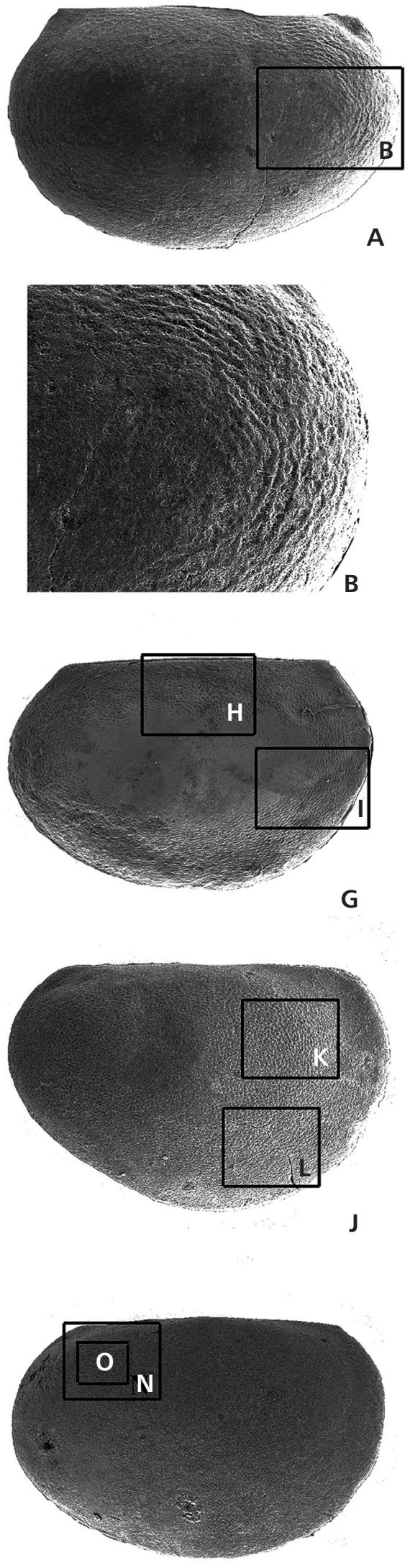

M
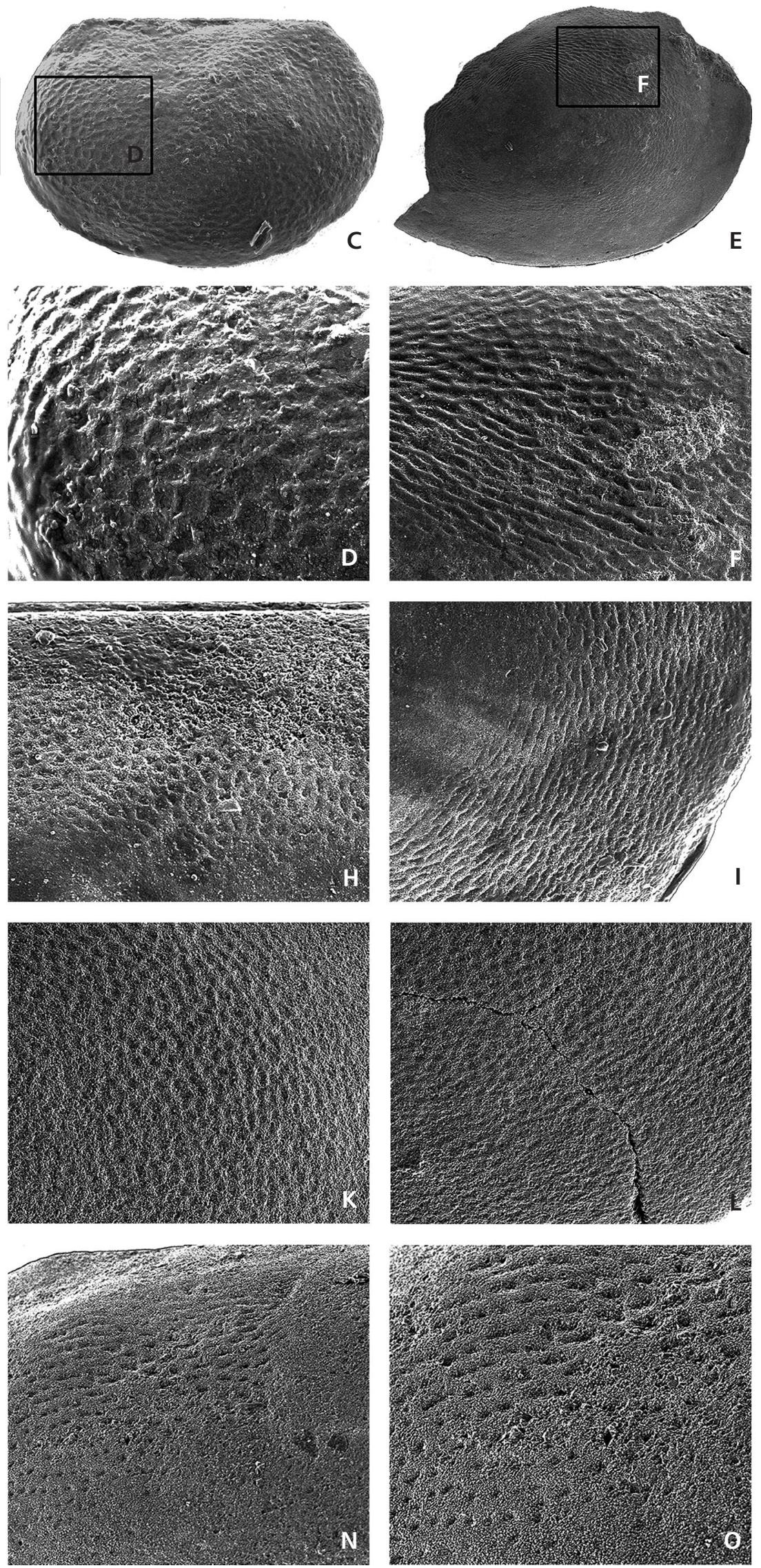
(op. cit.) as being densely covered with minute punctae, with the exception of the central swelling. It was also mentioned, that sometimes the punctae were very closely spaced and gave the impression of an extremely fine reticulum. According to the description, somewhat deeper punctae were scattered among the minute ones in the anterior part of the valve. Type $\beta$ was described as often more distinctly punctate, but lacking the scattered deep punctae.

Conchoides meganotifera Hessland, 1949 was described as having a minutely and more or less distinctly pitted or reticulate surface in type $\alpha$ and an often extremely finely rugose marginal surface in type $\beta$. Conchoides ventropunctata Hessland, 1949 was described with a very slightly rugose surface over the greater part, distinctly punctate centroventral field and with a few punctae on the anterior part of the valve.

Five species were described as having variably reticulate, striate or rugose carapace surfaces. Conchoides dorsodepressula (Hessland, 1949) shows extremely fine reticulation in the dorsocentral area, and Conchoides levis Hessland, 1949 shows mostly a smooth surface in type $\alpha$, but type $\beta$ has a microstriate area just in front of the dorsocentral swollen spot.

Conchoides sp. D was distinguished by its rugose surface (rugae observed in the anterior part of the dorsocentral area, marginally less distinct); rugae are short, narrow and somewhat wrinkled, and to a great extent anastomising, thus giving a reticulate appearance to some parts of the valve where the rugae are arranged longitudinally. Conchoides rugosa Hessland, 1949 shows a central rugose area, with anterior and posterior striae. Conchoides circumstriata Hessland, 1949 shows a central unsculptured region, surrounded by a marginal striate zone; in the dorsal area the striae may be arranged to form a reticulum. Conchoprimites reticulifera Hessland, 1949 shows a reticulate surface, except for marginal zones of different width, which are smooth or only faintly rugose.

It is noteworthy that Hessland (1949) described all his species from the Siljan district, from a rather restricted area with about ten localities, from the same very narrow stratigraphical interval, referred to as the "Täljsten" (see Fig. 2). This is a thin (up to $2 \mathrm{~m}$ ), grey-coloured limestone unit, marking a minor shallowing episode in the generally red-coloured limestone succession and dated as the lower Kunda Stage (lower Darriwilian), within the Asaphus expansus trilobite Biozone. The description above offers a nearly continuous transition from fairly smooth to coarsely ornamented forms. It is obvious that the lack of visible ornamentation may be due to preservation, but various kinds of transitions were documented by several investigators (Öpik 1937, Henningsmoen 1954, Sarv 1959). "Species" such as Conchoides dorsodepressula, Conchoides meganotifera, Conchoides sp. D, Conchoides socialis and
Conchoides micropunctata have been recorded from the lower part of the studied succession, while Conchoides sp. B, Conchoides levis, Conchoides circumstriata and Conchoides ventropunctata have been recorded from the upper part. In total Hessland's collection of Conchoprimites, Conchoprimitia and Conchoides comprises about 90 specimens.

C. luxuriosa Sarv, 1959 from an erratic boulder of Kunda age shows distinct, coarsely punctate sculpture, where the only impunctate areas are the median shield-like swelling plus the areas along the free margin and the hinge-line.

\section{Taphonomy and palaeogeographical distribution}

The analysis of the new collection of Conchoprimitia from the whole Baltoscandian area reveals a complicated picture. Careful examination of all specimens with satisfactory preservation showed considerable variation in carapace sculpture from within one locality and even within one sample. Punctation (Fig. 6) may vary from fine to coarse, with a transition to a rugose or reticulate surface. The sculpture may be clear and deep, or may be extremely shallow and hardly discernible. The sculpture may cover the whole carapace, the marginal area, a circular area around the central shield or only small patches near the adductor area. In addition to transitions from one sculpture type to another (Fig. 7), simultaneous co-occurrence of fine, shallow sculpture and deep, scattered punctae has been observed.

This kind of variation could likely, entirely or in part, be ascribed also to differences in preservation and taphonomic conditions. Fine sculpture on an ostracode carapace is rarely perfectly preserved and an almost smooth carapace may be the result of fine abrasion. However, making a distinction between the originally smooth and a worn surface in recrystallised fossil material is problematic.

Although ornamentation of the valves is variable, some palaeogeographical distribution pattern of the ornamentation could be noted, and therefore this variation was analyzed in detail. Palaeogeography and facies distribution in the Ordovician Baltoscandian Palaeobasin, originally documented by Männil (1966) and Jaanusson (1976, 1982), is shown in Fig. 8. The palaeobasin was mostly interpreted (Männil 1966; Jaanusson 1976, 1982) to represent a shallow and fairly uniform environment. However, the ostracode assemblage data (Tinn \& Meidla 1999, 2001; Tinn et al. 2006) have suggested differences between the marginal North Estonian, the mostly offshore Central Baltoscandian and the far offshore Scanian Confacies zones in the early Middle Ordovician, and this supports the notion that the confacies belts reflect a rough depth zonation of the palaeobasin (Männil \& Meidla 1994). 


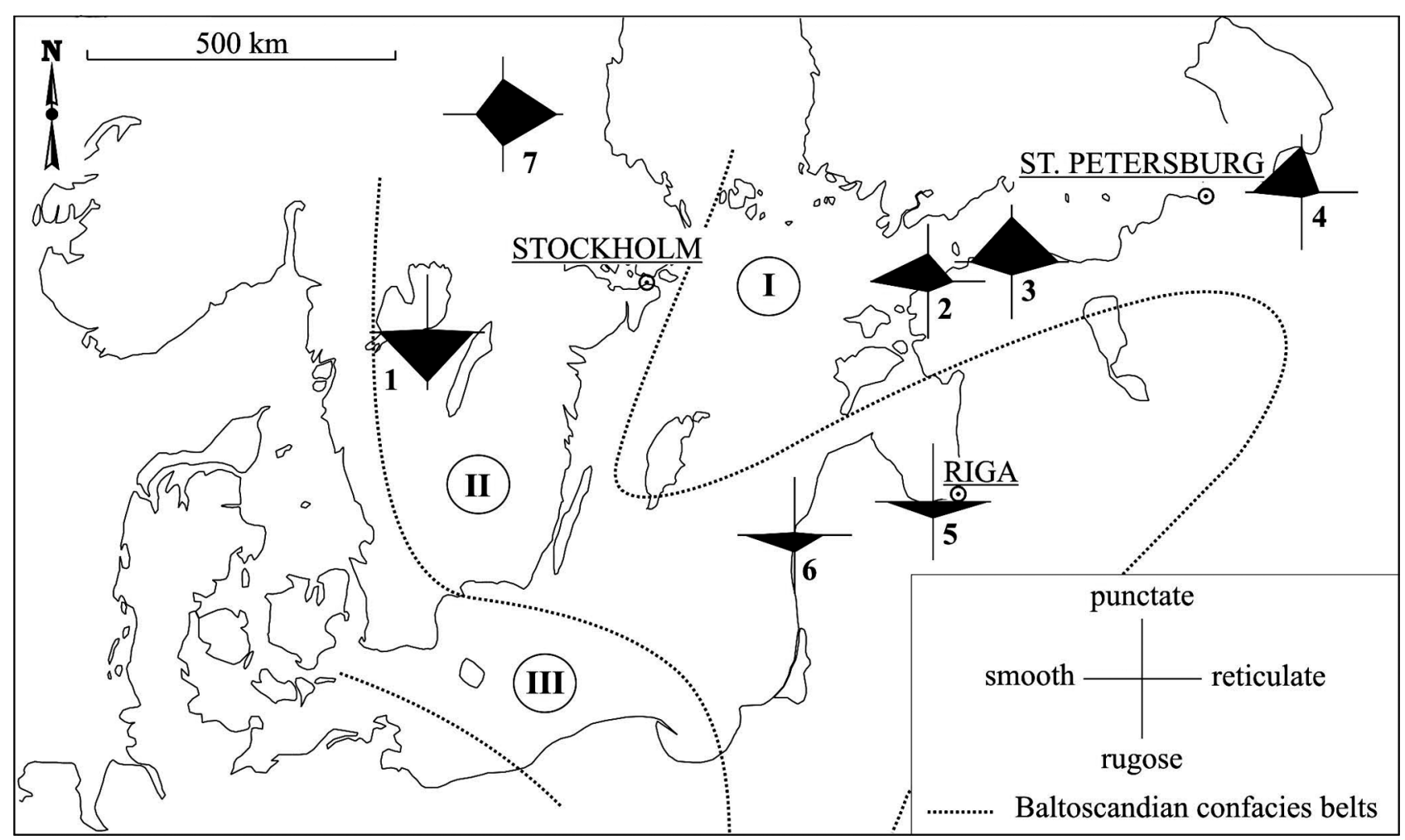

Figure 8. Relative frequencies of four main microsculpture types in Conchoprimitia socialis (Brøgger, 1882) at different localities. 1 - Hällekis, 2 - Väike-Pakri, 3 - Nőmmeveski, 4 - Lava, 5 - Jurmala, 6 - Vergale, 7 - Siljan. Roman numerals mark Ordovician Baltoscandian confacies belts after Jaanusson (1976). I - North Estonian Confacies Belt; II - Central Baltoscandian Confacies Belt; III - Scanian Confacies Belt.

Conchoprimitia species have been documented in all confacies belts of the study area. In order to analyze the distribution pattern in the palaeobasin, the carapace micro-sculpture was categorized into four types: smooth, punctate, reticulate and rugose.

The distribution of specimens with different types was documented in seven sections: Hällekis, Väike-Pakri, Nõmmeveski, Lava, Jurmala and Vergale sections. For comparison, the data on various species described by Hessland (1949) from the Siljan district was similarly analysed using the same methodology.

The data is plotted in Fig. 8. The Väike-Pakri, Nõmmeveski and Lava sections are dominated by punctate specimens, while the proportion of both smooth and reticulate specimens is considerable, but the number of rugose specimens is small. The Hällekis section shows a considerable number of rugose specimens, but the rest are specimens with smooth or reticulate carapaces; almost no punctate specimens were recorded from the Hällekis section.

The Jurmala and Vergale sections yield mostly smooth and reticulate specimens; the number of rugose specimens is minimal, and punctate specimens are absent. The specimens from the Siljan district (Hessland 1949) are most commonly reticulate, while specimens with punctate, smooth or rugose ornamentation are less common.
No significant temporal variation in carapace sculpture up through the rock succession has been recorded. Except for the fact that punctate specimens seem to be confined mainly to the shallower areas of the palaeobasin, there is no distinct depth-zonation in the distribution of the specimens either. Such a distribution pattern does not speak in favour of several distinct species groups.

A noteworthy feature among the studied specimens is the level of distinctness of the carapace sculpture. The specimens in the North Estonian Confacies belt and Siljan district show higher, better developed micro-sculpture than the specimens in the Hällekis, Jurmala and Vergale sections. In the latter sections, the sculpture has lower relief, and in some cases is hardly discernible.

\section{Discussion and conclusions}

In the Middle Ordovician Baltoscandian Palaeobasin, the carapace morphology of Conchoprimitia socialis shows considerable variation. However, the numerous morphotypes cannot be considered discrete taxonomic entities as the characters previously used to define them are shown to overlap. Specimens from a single bed may show clear transitions between different types of sulcation and microsculpture, and indeed even with smooth forms. 
Such a pattern speaks in favour of one polymorphic species rather than numerous distinct species populating the early Middle Ordovician Palaeobasin. Polymorphism, both in recent and fossil marine ostracodes has been repeatedly discussed (Reyment et al. 1988, Carbonel \& Hoibian 1988, Ikeya \& Ueda 1988, Carbonel \& Hamoudi 1990, Ducasse et al. 1998, Neil 2000, van Harten 2000). Peypoquet et al. (1988) have even speculated that ostracodes are physiologically and genetically predisposed to polymorphism. They discussed environmentally induced polymorphism in ostracodes, where the primary factor determining the architecture of the ostracode shell was carbonate concentration in the water, in turn dependent on climatic and physiogeographic conditions of the basin. Two main types of polymorphism in sculpture - degrading (smoother, less reticulate and thinner) and agrading (more reticulate and thicker) were distinguished. According to the authors, the most influential factors were temperature (when high temperature favours deposition of carbonates in the carapace and therefore encourages formation of more sculptured forms), and depth (often linked to temperature). Among the places likely to be affected were littoral areas, river bays, and regions with strong seasonal variation, where both morphs may occur.

Most of the features described above are applicable to Conchoprimitia in the early Middle Ordovician Baltoscandian Palaeobasin. Previous studies (Henningsmoen 1965, Siveter 1984) have shown that Ordovician ostracodes, including numerous palaeocope taxa and conchoprimitiids with their heavily calcified carapaces, were most likely bottom-dwellers. Based on this assumption, differences in the fine micro-sculpture of Conchoprimitia may have resulted from different bottom conditions, and this picture may then be further obscured by taphonomy.

Because of the high number of transitional morphotypes and co-occurrence of different types of microsculpture on the same carapaces, no distinction can be made between species groups in our collection. From the taxonomic point of view such a conclusion means that our new collection contains only one polymorphic species, and according to the priority rules this is Conchoprimitia socialis (Brøgger, 1882).

As numerous species have formerly been defined according to the features which are considered to vary widely among the specimens of this polymorphic species, and as such species are mostly based on a very limited number of specimens, we also conclude that during the early Middle Ordovician (Floian to early Darriwilian) time the Baltoscandian Palaeobasin was largely inhabited by one species of the genus Conchoprimitia - Conchoprimitia socialis (Brøgger, 1882). The species regarded as synonyms of $C$. socialis are listed in Table 1.

C. socialis was an opportunistic and tolerant species that was able to inhabit different kinds of facies/micro- habitats in the Baltoscandian Palaeobasin. Due to differences between the habitats, the species attained different valve ornamentation.

The Baltoscandian Palaeobasin was characterized by a distinct biofacies pattern during the early Middle Ordovician (Tinn 2002, Tinn et al. 2006). C. socialis occurs together with $O$. bocki, B. palmata, R. mitis, $P$. grewingki and several species of Euprimites a.o. Within this fauna, C. socialis is the only frequent species with basin-wide distribution. In most studied samples the percentage of C. socialis lies between $10-50 \%$, the highest percentage for an eridostracan in the Ordovician of Baltoscandia.

\section{Acknowledgements}

This work was funded by the Estonian Science Foundation grants 7087 and 8049, and target funding program project SF0180051s08. We also wish to acknowledge IGCP project 503. The authors thank Solweig Stuenes from the Palaeontological Museum of Uppsala and the staff from the Palaeontological Museum of Oslo for access to specimens in their care. The authors also thank Giles Miller, Joseph Botting, Jean Vannier and especially Mark Williams, who critically read the earlier versions of the manuscript and offered many helpful comments.

\section{References}

ADAMCZAK, F. 1961. Eridostraca - a new suborder of ostracodes and its phylogenetic significance. Acta Palaeontologica Polonica 6, 29-102.

AinsaAR, L., Meidla, T., Tinn, O. \& Stinkulis, G. 2002. The "Volkhov Collector" in western Latvia - a siliciclastic turbidite bed in the Ordovician epeiric carbonate basin, 11-13. In SATKUNAS, J. \& LAZAUSKIENE, J. (eds) Basin stratigraphy modern methods and problems. The Fifth Baltic Stratigraphical Conference, Vilnius.

BRøGGER, W.C. 1882. Die Silurischen Etagen 2 und 3 im Kristianiagebiet und auf Eker, ihre Gliederung, Fossilien, Schichtenstörungen und Contactmetamorphosen. 376 pp. Universitets-Program, 2. Semester, A.W. Brøgger, Kristiania.

CARBONEL, P. \& HAMOUdI, M. 1990. Le variabilité morphologique chez Lindisfarnia guttata un indice de l'hydrologie du plateau continental Atlantique Marocain. Geobios 23, 343-348. DOI 10.1016/0016-6995(90)80005-Z

CARBOnEl, P. \& HoIBIAN, T. 1988. The impact of organic matter on ostracodes from an equatorial deltaic area, the Mahakam delta - Southeastern Kalimantan, 353-366. In HANAI, T., IKEYA, N. \& ISHIZAKI, K. (eds) Evolutionary biology of Ostracoda. Kodansha, Tokyo.

Carbonel, P., Peypouquet, J.P., Braccini, E. \& Kasimi, R. 1990. Le polymorphisme induit par l'environnement chez Hermanites et sa relation avec le changement de regime climatique au passage Plio-Pleistocene. Revue de Micropaleontologie 33, 269-278.

Dronov, A., Holmer, L., Meidla, T., Sturesson, U., TinN, O. \& AINSAAR, L. 2001. Detailed litho- and sequence stratig- 
raphy of the "Täljsten" Limestone unit and its equivalents in the Ordovician of Baltoscandia, 8-9. In HARPER, D.A.T. \& STOUGE, S. (eds) WOGOGOB-2001. Working Group of the Ordovician Geology of Baltoscandia. Oresund Region, mid-May, 2001.

Ducasse, O., Rousselle, L. \& BeKaert, O. 1990. Adaptive strategies and evolutionary processes in ostracoda: examples from the Eocene-Oligocene boundary of the northern Aquitaine Basin, 459-464. In WHATLEY, R. (ed.) International symposium on Ostracoda. Maybury.

HENNINGSMOEN, G. 1954. Lower Ordovician Ostracods from the Oslo Region, Norway. Norsk Geologisk Tidsskrift 33, 41-68.

HENNINGSMOEN, G. 1965. On certain features of palaeocope ostracodes. Geologiska Föreningens i Stockholm Förhandlingar 86, 329-394.

HESSLAND, I. 1949. Investigations of the Lower Ordovician of the Siljan District, Sweden, I. Lower Ordovician Ostracodes of the Siljan District. The Bulletin of the Geological Institutions of Uppsala 33, 97-408.

IKEYA, N. \& UEDA, H. 1988. Morphological variations of Cytheromorpha acupunctata (Brady) in continuous populations at Hamana-ko bay, Japan, 319-340. In HANAI, T., IKEYA, N. \& ISHIZAKI, K. (eds) Evolutionary biology of Ostracoda. Kodansha, Tokyo.

JAANUSSON, V. 1957. Middle Ordovician Ostracodes of Central and Southern Sweden. The Bulletin of the Geological Institutions of the University of Uppsala 37, 173-442.

JAANUSSON, V. 1976. Faunal dynamics in the Middle Ordovician (Viruan) of Balto-Scandia, 301-326. In BASSETT, M.G. (ed.) The Ordovician System: proceedings of a Palaeontological Association symposium, Birmingham, September 1974. University of Wales Press and National Museum of Wales, Cardiff.

JAANUSSON, V. 1982. Ordovician in Västergötland, 164-183. In BRUTON, D.L. \& WiLliams, S.H. (eds) Field excursion guide. IV. International Symposium of the Ordovician System. Paleontological Contributions from the University of Oslo 279.

KrAUSE, A. 1889. Ueber Beyrichien und verwandte Ostracoden in untersilurischen Geschieben. Zeitschrift der Deutschen geologischen Gesellschaft 41, 1-26.

KRAUSE, A. 1891. Beitrag zur Kenntniss der Ostrakoden-Fauna in silurischen Diluvialgeschieben. Zeitschrift der Deutschen geologischen Gesellschaft 43, 488-521.

KuMMEROW, E. 1924. Beiträge zur Kenntnis der Ostracoden und Phyllocariden aus nordischen Diluvialgeschieben. Jahrbuch der Preussischen Geologischen Landesanstalt 44, 405-448.

LÖFGREN, A. 1995. The middle Lanna/Volkhov Stage (middle Arenig) of Sweden and its conodont fauna. Geological Magazine 132, 693-711. DOI 10.1017/S0016756800018926

LÖFGREN, A. 2000. Conodont biozonation in the upper Arenig of Sweden. Geological Magazine 137, 53-65. DOI 10.1017/S0016756800003484

MÄNNIL, R. 1966. Istoriya razvitiya Baltiiskogo basseina $v$ ordovike [Evolution of the Baltic Basin during the Ordovician]. 200 pp. Eesti NSV Teaduste Akadeemia Geoloogia Instituut, Tallinn. [in Russian, English summary]

MÄnNIL, R. \& MEIDLA, T. 1994. The Ordovician System of the East European Platform (Estonia, Latvia, Lithuania, Byelorussia, parts of Russia, the Ukraine, and Moldova), 1-52. In
WebBy, B.D. \& Williams, S.H. (eds) The Ordovician System of the East European Platform and Tuva (Southeastern Russia). IUGS Publication.

Meidla, T., AinsaAR, L. \& TinN, O. 1998. Volkhov Stage in North Estonia and sea level changes. Proceedings of the Estonian Academy of Sciences, Geology 47, 141-157.

MELNIKOVA, L.M. 1999. Ostracodes from the Billingen Horizon (Lower Ordovician) of the Leningrad Region. Paleontological Journal 33, 147-152.

NEIL, J.V. 2000. Factors influencing intraspecific variation and polymorphism in marine podocopid Ostracoda, with particular reference to Tertiary species from southeastern Australia. Hydrobiologia 419, 161-180.

DOI 10.1023/A:1003983918339

NÕLVAK, J., HINTS, O. \& MÄNNIK, P. 2006. Ordovician timescale in Estonia; recent developments. Proceedings of the Estonian Academy of Sciences, Geology 55, 95-108.

ÖPIK, A. 1935. Ostracoda from the lower Ordovician Megalaspis-limestone of Estonia and Russia. Publications of the Geological Institutions of the University of Tartu 44, 1-12.

ÖPIK, A. 1937. Ostracoda from the Ordovician Uhaku and Kukruse formations of Estonia. Publications of the Geological Institutions of the University of Tartu 50, 1-59.

ÖPIK, A. 1939. Brachiopoden und Ostrakoden aus dem Expansusschiefer Norwegens. Norsk Geologisk Tiddsskrift 19, $17-142$.

Owen, A.W., Bruton, D.L., Bockelie, J.F. \& Bockelie, T.G. 1990. The Ordovician successions of the Oslo Region, Norway. Norges geologiske undersøkelse Special Publication 4, $1-54$.

PARK, L.E., MARTENS, K. \& COEN, A.S. 2002. Phylogenetic relationships of Gomphocythere (Ostracoda) in Lake Tanganyika, East Africa. Journal of Crustacean Biology 22, 15-27. DOI 10.1651/0278-0372(2002)022[0015:PROGOI]2.0.CO;2

PARK, L.E. \& RICKETTS, R.D. 2003. Evolutionary history of the Ostracoda and the origin of the nonmarine faunas. The Paleontological Society Papers 9, 11-35.

Peypoquet, J.P., Carbonel, P., Ducasse, O., TöldererFARMER, M. \& LÉTÉ, C. 1988. Environmentally cued polymorphism of ostracods, 1003-1019. In HANAI, T., IKEYA, N. \& ISHIZAKI, K. (eds) Evolutionary biology of Ostracoda. Kodansha, Tokyo.

REYMENT, R.A., BoOKSTEIN, F.L., MCKEnZIE, K.G. \& MAJORAN, S. 1988. Ecophenotypic variation in Mutilus pumilus (Ostracoda) from Australia, studied by canonical variate analysis and tumor biometrics. Journal of Micropalaeontology 7 , 11-20. DOI 10.1144/jm.7.1.11

SARV, L. 1959. Ostrakody ordovika Estonskoj SSR [Ordovician Ostracodes in the Estonian S.S.R.]. 206 pp. ENSV Teaduste Akadeemia Geoloogia Instituudi Uurimused 4. [in Russian, English summary]

SCHALlREUTER, R. 1977. On Cryptophyllus gutta Schallreuter. Stereo-Atlas Ostracod Shells 4, 1-18.

SCHALLREUTER, R. 1993. Ostrakoden aus ordovizischen Geschieben II. Beiträge zur Geschiebekunde Westfalens 2. Geologie und Paläontologie in Westfalen 27, 1-273.

SIDARAVIČIENĖ, N. 1992. Ostrakody ordovika Litvy [Ordovician ostracodes of Lithuania]. 251 pp. Vilnius. [in Russian]

SiVETER, D. 1984. Habitats and mode of life of Silurian ostracodes. Special Papers in Palaeontology 32, 71-85. 
SIVETER, D.J. 2008. Ostracods in the Palaeozoic? Senckenbergiana lethaea $88(1), 1-9$.

Siveter, D.J., SutTon, M.D. \& BRIGGS, D.E.G. 2003. An ostracode crustacean with soft parts from the lower Silurian. Science 302(5651), 1749-1751.

DOI 10.1126/science.1091376

STEUSLOFF, A. 1895. Neue Ostrakoden aus Diluvialgeschieben von Neu-Brandenburg. Zeitschrift der Deutschen geologischen Gesellschaft 46, 775-787.

THORSLUND, P. 1940. On the Chasmops series of Jemtland and Södermanland (Tvären). Sveriges geologiska undersökning C $436,1-191$.

TINN, O. 2002. Early Ostracode Evolution and Palaeoenvironmental Application in the Ordovician of Baltoscandia. $145 \mathrm{pp}$. Dissertationes Geologicae Universitatis Tartuensis 13, Tartu University Press.

TinN, O. \& MEIDLA, T. 1999. Ordovician ostracodes from the Komstad Limestone. Bulletin of the Geological Society of Denmark 46, 25-30.

TinN, O. \& MEIDLA, T. 2001. Middle Ordovician ostracodes from the Lanna and Holen limestones, South-Central Sweden, Geologiska Föreningens i Stockholm Förhandlingar 123, 129-136.
Tinn, O., MEIDla, T. \& AinsaAR, L. 2006. Arenig (Middle Ordovician) ostracods from Baltoscandia: Fauna, assemblages and biofacies. Palaeogeography, Palaeoclimatology, Palaeoecology 241, 498-514. DOI 10.1016/j.palaeo.2006.05.002

TINN, O. \& OAKLEY, T.H. 2008. Erratic rates of molecular evolution and incongruence of fossil and molecular divergence time estimates in Ostracoda (Crustacea). Molecular Phylogenetics and Evolution 48(1), 157-167.

DOI 10.1016/j.ympev.2008.03.001

VAN HARTEN, D. 2000. Variable noding in Cyprideis torosa (Ostracoda, Crustacea): an overview, experimental results and a model from Catastrophe Theory. Hydrobiologia 419, 131-139. DOI 10.1023/A:1003935419364

VANNIER, J.M.C., SiVETER, D.J. \& SCHALlREUTER, R.E.L. 1989. The composition and palaeogeographical significance of the Ordovician ostracode faunas of Southern Britain, Baltoscandia, and Ibero-Armorica. Palaeontology 32, 163-222.

WiLliAMS, M., STEPHENSON, M., WILKINSON, I.P., LENG, M.J. \& MilleR, C.G. 2005. Early Carboniferous (late Tournaisian-early Viséan) ostracods from the Ballagan Formation, central Scotland, UK. Journal of Micropalaeontology 24, 77-94. DOI 10.1144/jm.24.1.77 